\title{
The Effect of Incubation Temperature on the Species Composition of Phytophthora, Phytopythium, and Pythium Communities Associated with Soybean
}

\author{
Krystel A. Navarro-Acevedo, ${ }^{1,2}$ Saranga Wijeratne, ${ }^{3}$ Steve W. Culman, ${ }^{4}$ Maria-Soledad Benitez, ${ }^{1}$ and Anne E. Dorrance ${ }^{1,2 \dagger}$ \\ ${ }^{1}$ Department of Plant Pathology, The Ohio State University Ohio Agricultural Research and Development Center (OARDC), Wooster, OH \\ 44691, U.S.A. \\ ${ }^{2}$ Center for Applied Plant Sciences and Center for Soybean Research, The Ohio State University, Columbus, OH 43210, U.S.A. \\ ${ }^{3}$ Molecular and Cellular Imaging Center, The Ohio State University OARDC, Wooster, OH 44691, U.S.A. \\ ${ }^{4}$ School of Environment and Natural Resources, The Ohio State University, Wooster, OH 44601, U.S.A.
}

Accepted for publication 17 November 2020.

\section{ABSTRACT}

Multiple species of Phytophthora, Phytopythium, and Pythium cause detrimental effects to soybean and more than one species have often been recovered from symptomatic soybean seedlings or roots, suggesting that these occur as species complexes. Our objective was to assess the species diversity and abundance of Phytophthora, Phytopythium, and Pythium spp. associated with soybean seedlings at two different incubation temperatures from soils collected from the same 81-ha farm but from five fields with a different history of production practices. To determine the effect of incubation temperature on the species detected, soils were baited with soybean seedlings at 15 and $25^{\circ} \mathrm{C}$. At each temperature, isolates were directly recovered from seedling roots and the associated rhizosphere soil was assayed via amplicon sequencing with oomycete-specific primers. Regardless of incubation temperature or field site, the species Pythium sylvaticum and
Pythium ultimum were isolated through the baiting procedure and these, along with Pythium acrogynum, Pythium attrantheridium, and Pythium heterothallicum, were detected with amplicon sequencing. Some Pythium spp. were more abundant at $15^{\circ} \mathrm{C}$ while others were favored at $25^{\circ} \mathrm{C}$. This study demonstrated that the species diversity of Phytophthora, Phytopythium, and Pythium detected on seedling roots and in the rhizosphere of soybean can be influenced by incubation temperature. This may explain, in part, the differences in the species composition reported from previous surveys and suggests that production practices associated with each of the sampled fields may have influenced the species complexes of Phytophthora, Phytopythium, and Pythium.

Keywords: agriculture, microbiome, molecular biology, oomycetes, phyllosphere, plant pathology, plants, rhizosphere
Oomycetes encompass a wide range of organisms that are found in many niches, including agricultural fields (Fry and Grünwald 2010; Martin and Loper 1999; Robideau et al. 2011; Schroeder et al.

\section{${ }^{\dagger}$ Corresponding author: A. E. Dorrance; dorrance.1@osu.edu}

Funding: This project was supported, in part, by The Ohio State University Graduate School through the Summer Research Opportunity Program to K. Navarro-Acevedo, Syngenta Crop Protection, and Ohio Soybean Council. Salaries and research support for this project were provided by State and Federal Funds appropriated to the Ohio Agricultural Research and Development Center, The Ohio State University, and the United States Department of Agriculture-National Institute of Food and Agriculture, Hatch project Development of Disease Management Strategies for Soybean Pathogens in Ohio (OH001303).

*The $\boldsymbol{e}$-Xtra logo stands for "electronic extra" and indicates that two supplementary figures and three supplementary tables are published online.

The author(s) declare no conflict of interest.

(C) 2021 The American Phytopathological Society
2013). They are closely related to brown algae and diatoms but their filamentous growth resembles that of true fungi. Many members have saprophytic lifestyles yet some are very important plant pathogens. Species of the genera Phytophthora, Pythium, Phytopythium, and Globisporangium, often referred to as water molds, are among the most important members of Oomycetes due to their pathogenicity and economic impact on a large number of crops (de Cock et al. 2015; Hendrix and Campbell 1973; Lévesque and de Cock 2004; Martin and Loper 1999; Robideau et al. 2011; Schroeder et al. 2013; Uzuhashi et al. 2010). The genus Globisporangium encompasses the species with globose or round sporangia previously classified as Pythium (Uzuhashi et al. 2010). This study relies on older voucher specimens for identification prior to the change of the genus name; thus, we will refer to Globisporangium as Pythium.

In the north-central region of the United States, more than 25 species of Pythium, Phytophthora sansomeana, and Phytophthora sojae have been reported as important pathogens of soybean and 
corn (Broders et al. 2007, 2009; Dorrance 2018; Jiang et al. 2012; Radmer et al. 2017; Rojas et al. 2017a; Zhang and Yang 2000; Zitnick-Anderson and Nelson 2015). Early-season symptoms include pre- and postemergence damping-off of soybean seed and seedlings, while root rot can occur throughout the entire season, with reported losses from 2010 to 2014 of 6.5 billion metric tons in the United States (Allen et al. 2017). Management practices include fungicide seed treatments and resistant cultivars, as well as agricultural practices such as crop rotation to prevent rapid buildup of inoculum and tillage to increase soil drainage (Broders et al. 2007; Dorrance et al. 2004, 2008; Schmitthenner and Van Doren 1985; Zhang et al. 1998).

Pathogenicity and aggressiveness of several species of Phytophthora, Phytopythium, and Pythium are known to be greatly influenced by temperature (Hendrix and Campbell 1973). For example, disease development in soybean was favored by lower temperatures of 15 to $20^{\circ} \mathrm{C}$ for Pythium debaryanum and Pythium ultimum (Thomson et al. 1971) and $13^{\circ} \mathrm{C}$ for Pythium torulosum and Pythium lutarium (Matthiesen et al. 2016). Radmer et al. (2017) reported that, as temperature increased from 15 to $25^{\circ} \mathrm{C}$, there was greater disease severity for 16 of 21 Pythium and Phytopythium spp. from Minnesota. However, similar levels of disease severity were reported for isolates of Pythium sylvaticum from Iowa at 18 and $23^{\circ} \mathrm{C}$ (Matthiesen et al. 2016). Higher temperatures (between 24 and $36^{\circ} \mathrm{C}$ ) favored infection and disease development of soybean by Pythium aphanidermatum (Thomson et al. 1971) and $25^{\circ} \mathrm{C}$ for Phytophthora sojae (Kaufmann and Gerdemann 1958).

Several surveys of soybean seedling pathogens have evaluated the association of soil edaphic factors such as soil $\mathrm{pH}$, calcium, magnesium, organic matter content, or cation exchange capacity (CEC) with species distribution and oomycete community composition (Broders et al. 2009; Rojas et al. 2017b; Zitnick-Anderson et al. 2017). From a survey of 88 fields in Ohio, 5,000 isolates of Pythium were identified and, from this collection, five distinct communities were identified using cluster analysis. These communities were significantly influenced by the clay and silt content of the soils (Broders et al. 2009). Other soil properties such as $\mathrm{pH}$, calcium, magnesium, organic matter content, and CEC of the soils were also significantly associated with the community composition of Pythium (Broders et al. 2009). Similar results were reported from 3,418 isolates recovered from diseased soybean seedlings in a survey of 125 fields in the north-central region of the United States and Canada (Rojas et al. 2017a). They reported that latitude, precipitation, temperature, soil clay content, and soil water content were significantly associated with species abundance and composition (Rojas et al. 2017b). Additionally, Zitnick-Anderson et al. (2017) reported that higher levels of zinc favored Pythium ultimum, higher CEC favored Pythium kashmirense, and both CEC and calcium carbonate exchange favored Pythium heterothallicum and Pythium irregulare. In media, zinc has been shown to be an essential component in the development of Pythium oogonia and vegetative growth (Lenney and Klemmer 1966) but higher levels of zinc were also shown to inhibit zoospore activity (Donaldson and Deacon 1993).

Direct isolation or recovery of Phytophthora, Phytopythium, and Pythium spp. from soils can be challenging, and a soil-baiting technique (Erwin and Ribeiro 1996) is the method used to assess inter- and intraspecies diversity and abundance, as reported in many studies (Broders et al. 2007; Dorrance et al. 2004; Jiang et al. 2012; Radmer et al. 2017; Zhang and Yang 2000; Zitnick-Anderson and Nelson 2015). This method combines intermittent flooding events and incubation periods to break the dormancy of the survival structures (oospores), and to enhance the production of asexual structures (sporangia) as well as a susceptible host plant to bait for pathogenic species (Erwin and Ribeiro 1996). However, many samples must be collected to truly assess the species diversity of Phytophthora, Phytopythium, and Pythium in any soil sample, and the use of this technique alone can limit recovery, especially if multiple species are present. With advances in sequencing technologies, detection of microorganisms from soils can now be evaluated in a high-throughput manner. Amplicon sequencing has been beneficial in the detection of oomycete species associated with disease of wheat (Bakker et al. 2017) and corn (Rojas et al. 2019), and to determine the spatial and temporal dynamics of oomycetes in recycled irrigation water of a commercial container nursery (Redekar et al. 2019). Amplicon sequencing allows for the assessment of species diversity of Phytophthora, Phytopythium, and Pythium associated with soybean, removing the limitations and difficulties often encountered with direct isolation.

The influence of soil incubation temperature on pathogenicity and aggressiveness of Pythium spp. has been evaluated in controlled greenhouse studies. However, the effects of incubation temperature on the detection of Phytophthora, Phytopythium, and Pythium spp. when soil edaphic factors remain constant has not been explored. Thus, the objective of this study was to assess the effects of incubation temperature on the species of Phytophthora, Phytopythium, and Pythium associated with the rhizosphere of soybean

TABLE 1

Description of agronomic practices and soil properties of five fields from The Ohio State University Northwest Agricultural Research Station in Wood County, OH

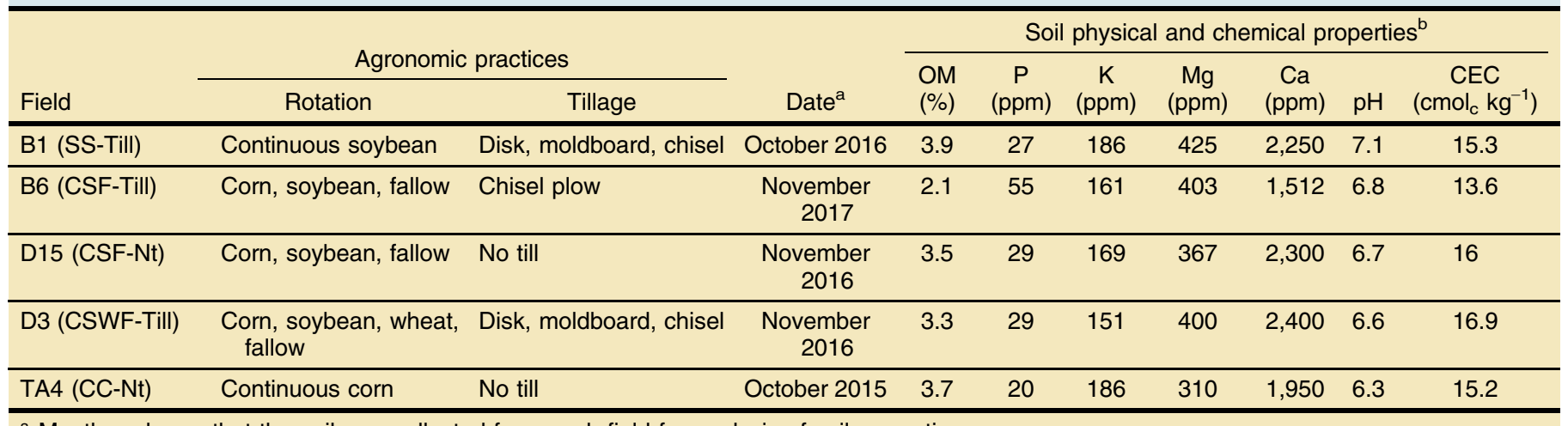

a Month and year that the soil was collected from each field for analysis of soil properties.

b Bray-P1 extractable cations. $\mathrm{OM}=$ organic matter and $\mathrm{CEC}=$ cation exchange capacity. 
seedlings from five separate fields with different agricultural practices. To accomplish this objective, soils were collected from an 81-ha research farm with similar physical and chemical properties. This approach removes any bias that may occur based on soil properties (Broders et al. 2009; Rojas et al. 2017b; ZitnickAnderson et al. 2017). Soils were used to evaluate the species recovered at two incubation temperatures using soil baiting with soybean seedlings with an amplicon sequencing approach of the rhizosphere soil, as well as direct isolation from symptomatic tissue. The primary hypothesis tested in this study was that the species diversity of Phytophthora, Phytopythium, and Pythium associated with soybean seedlings will be influenced by the soil-baiting incubation temperature.

\section{MATERIALS AND METHODS}

Site description and sample collection. Five separate fields at The Ohio State University Northwest Agricultural Research Station located in Wood County, $\mathrm{OH}$ were selected for this study (Supplementary Fig. S1). This research farm is located on 81 ha and has predominantly silty clay and silty clay loam soils which are very prone to compaction and poor drainage, with slopes of 0 to $1 \%$. The fields that were sampled were selected based on long-term studies conducted at this location that included soybean breeding plots and management studies of Phytophthora sojae. In addition, the crop rotation and tillage histories of each field site were available for each year beginning with 2012 (Table 1). The soil physical and chemical properties were assessed for each field in years 2015, 2016, or 2017 (Table 1). The soils from each field all had similar levels of organic matter, phosphorous, potassium, magnesium, and calcium. The $\mathrm{CEC}$ of each soil sample was also very similar and $\mathrm{pH}$ values ranged from 6.3 to 7.1 .

From each field, five soil samples of approximately 5.7 liters from the top $20 \mathrm{~cm}$ were collected with a shovel during January 2017. The samples were collected randomly and spaced at least $7.6 \mathrm{~m}$ apart in each field. The soils were transported to the laboratory and stored at $4^{\circ} \mathrm{C}$ until processed. Soils were air dried for $24 \mathrm{~h}$ in the greenhouse, then ground into fine particles using the IER Improved Soil Grinder (The Fen Machine Co., Cleveland, OH, U.S.A.) to homogenize samples and to make the heavy clay soil easier to handle for baiting. After this process, approximately $60 \%$ of the particles were less than $2 \mathrm{~mm}$. Field names were abbreviated to reflect the crop rotation scheme and tillage practice as follows: field TA4 with continuous corn and no till (CC-Nt), field B1 with continuous soybean and tilled (SS-Till), field B6 with cornsoybean-fallow rotation and tilled (CSF-Till), field D3 with cornsoybean-wheat-fallow rotation and tilled (CSWF-Till), and field D15 with corn-soybean-fallow and no till (CSF-Nt).

Soil baiting. To increase the detection of oomycetes species from soils, a baiting techniques was used (Broders et al. 2009; Erwin and Ribeiro 1996). Soils from each of the five field sites were divided and aliquots were placed into 0.09-liter pots. Pots were placed inside long polyvinyl trays and flooded for $24 \mathrm{~h}$ by adding deionized water. The water was drained from the trays and soils were dried in the pots until moisture levels reached approximately $300 \mathrm{mb}$ matric potential. Pots were then placed in plastic trays for ease of handling, covered with a polyethylene bag to maintain moisture, and incubated inside a growth chamber (CMP6010 Adaptis; Conviron, Winnipeg, $\mathrm{MB}$, Canada) at 15 or $25^{\circ} \mathrm{C}$. Each field was represented by five pots at each temperature. After 2 weeks, 10 seeds of the moderately susceptible soybean cultivar Sloan were placed on the surface of the soil of each pot, covered with wet coarse vermiculite, and incubated for three more days. After seed germinated, the pots were moved to the greenhouse, flooded a second time for $24 \mathrm{~h}$, and placed on a greenhouse bench to drain excess water. After 3 days, five seedlings were collected from each pot for direct isolation of pathogens. In addition, the corresponding rhizosphere soil of the five seedlings was collected by shaking the seedlings inside a manila envelope. Seedlings were processed immediately while rhizosphere soils were stored at $-20^{\circ} \mathrm{C}$ until used.

Pathogen direct isolation. Pathogen isolation was performed as previously described by Dorrance et al. (2008). Briefly, seedling roots were first washed with tap water to remove debris, then taken to a laminar flow hood. Root tissue was cut into pieces and placed in $70 \%$ ethanol for $10 \mathrm{~s}$ followed by a 30-s rinse with sterile distilled water. Roots were blotted dry between sterile paper towels and sections from the edge of the lesions were placed under V8-media + pentachloronitrobenzene, iprodione, benlate, neomycin sulfate, and chloramphenicol (PBNIC) selective media in a 60-by-15-mm Petri dish. After 3 days of incubation at $20^{\circ} \mathrm{C}$, cultures were examined for coenocytic growth of mycelia, and those without this characteristic were discarded. Hyphal tips of oomycete-like cultures were

TABLE 2

Shannon's diversity index (DI) for species of Phytophthora, Phytopythium, and Pythium spp. from rhizosphere soil collected from soybean seedlings grown in soil collected from five fields following incubation at 15 and $25^{\circ} \mathrm{C}$ during soil baiting (culture-independent analyses)

\begin{tabular}{|c|c|c|c|c|}
\hline Field, agronomic practice ${ }^{a}$ & Temp $\left({ }^{\circ} \mathrm{C}\right)^{\mathrm{b}}$ & Shannon's DI & Tukey & $P$ value \\
\hline B1 (SS-Till) & 25 & 1.62 & $A$ & 0.08 \\
\hline B6 (CSF-Till) & 25 & 1.69 & B & 0.003 \\
\hline D15 (CSF-Nt) & 15 & 1.61 & A & $\ldots$ \\
\hline \multirow[t]{2}{*}{ D3 (CSWF-Till) } & 15 & 1.68 & A & $\ldots$ \\
\hline & 25 & 1.27 & $A$ & 0.348 \\
\hline \multirow[t]{2}{*}{ TA4 (CC-Nt) } & 15 & 1.76 & $A$ & $\ldots$ \\
\hline & 25 & 1.24 & B & 0.003 \\
\hline
\end{tabular}

a Abbreviation for agronomic practices: SS-Till = continuous soybean and tilled; CSF-Till = corn, soybean, fallow, and tilled; CSF-Nt = corn, soybean, and fallow with no till; CSWF-Till = corn, soybean, wheat, fallow, and tilled; and CC-Nt = continuous corn with no till.

b Soil incubation temperature. 
transferred to potato carrot agar (PCA) plates amended with rifampicin antibiotic $(100 \mu \mathrm{g} / \mathrm{ml})$ to inhibit bacterial growth. Pure cultures were transferred to Whatman vials with PCA for long term storage at $15^{\circ} \mathrm{C}$.

Direct colony PCR and Sanger sequencing. Direct colony PCR was adapted from Broders et al. (2009) and Kong et al. (2005). Briefly, the internal transcribed spacer (ITS) 1 of the ribosomal RNA (rRNA) gene was amplified using the primers ITS6 (Cooke and Duncan 1997) and ITS7 (Cooke et al. 2000) from each individual isolate. A master-mix solution was prepared using the Promega GoTaq Polymerase Kit (Promega Corp, Madison, WI, U.S.A.). The solution consisted of $5 \mu \mathrm{l}$ of $5 \times$ colorless reaction buffer, $1.5 \mu \mathrm{l}$ of $\mathrm{MgCl}_{2}(25 \mathrm{mM}), 1 \mu \mathrm{l}$ of dNTPs $(10 \mu \mathrm{M}), 1 \mu \mathrm{l}$ of primers ITS6 (10 $\mu \mathrm{l}) 5^{\prime}$-GAAGGTGAAGTCGTAACAAGG-3' and ITS7 (10 $\left.\mu \mathrm{l}\right)$ 5'-AGCGTTCTTCATCGATGTGC-3' (Cooke et al. 2000), $0.25 \mu l$ of GoTaq DNA Polymerase ( $5 \mathrm{U} / \mu \mathrm{l})$, and $13.25 \mu \mathrm{l}$ of ultrapure water. In a 96-well plate, $23 \mu \mathrm{l}$ of the master mix was aliquoted into each well, and approximately $1 \mathrm{~mm}^{3}$ of mycelia from the edge of the plate of each isolate was transferred to individual wells and macerated with a sterile pipette tip. The plate was immediately placed in a PCR machine with the following parameters: $95^{\circ} \mathrm{C}$ for $5 \mathrm{~min}$; followed by 30 cycles of $94^{\circ} \mathrm{C}$ for $1 \mathrm{~min}, 53^{\circ} \mathrm{C}$ for $1 \mathrm{~min}$, and $72^{\circ} \mathrm{C}$ for $1 \mathrm{~min}$; and completed with $72^{\circ} \mathrm{C}$ for $5 \mathrm{~min}$. Quality and quantity of the amplicon were obtained by using both the $\mathrm{A}_{260} / \mathrm{A}_{280}$ and $\mathrm{A}_{260} / \mathrm{A}_{230}$ ratios with a spectrophotometer (Nanodrop 3300; Thermo Scientific, Vernon Hills, IL, U.S.A.) and electrophoresis of $2 \mu \mathrm{l}$ of the PCR product on a $1 \%$ (wt/vol) agarose gel for $1 \mathrm{~h}$ at $90 \mathrm{~V}$. The gel was stained with GelRed (Biotum, Fremont, CA, U.S.A.) and product visualized using a UV light transilluminator.

For each isolate, the amplicon was purified through an enzymatic process by mixing $2 \mu \mathrm{l}$ of ExoSAP-IT (Thermo-Fisher, Waltham, MA, U.S.A.) with $5 \mu \mathrm{l}$ of the PCR product, followed by a 5 -min incubation at $37^{\circ} \mathrm{C}$ and 15 -min incubation at $80^{\circ} \mathrm{C}$. After amplicon purification, $3 \mu \mathrm{l}$ of each individual primer at a concentration of 2 pmol was mixed with $6 \mu \mathrm{l}$ of the purified product at $20 \mathrm{ng} / \mu \mathrm{l}$. This mix was submitted to the Molecular and Cellular Imaging Center (MCIC) at the Ohio Agricultural Research and Development Center (OARDC) for Sanger sequencing using both forward and reverse primers. Sequences from both primers were quality filtered and assembled using Codon Code Aligner (Codon Code Corporation, Centerville, MA, U.S.A.). Sequences were then compared with

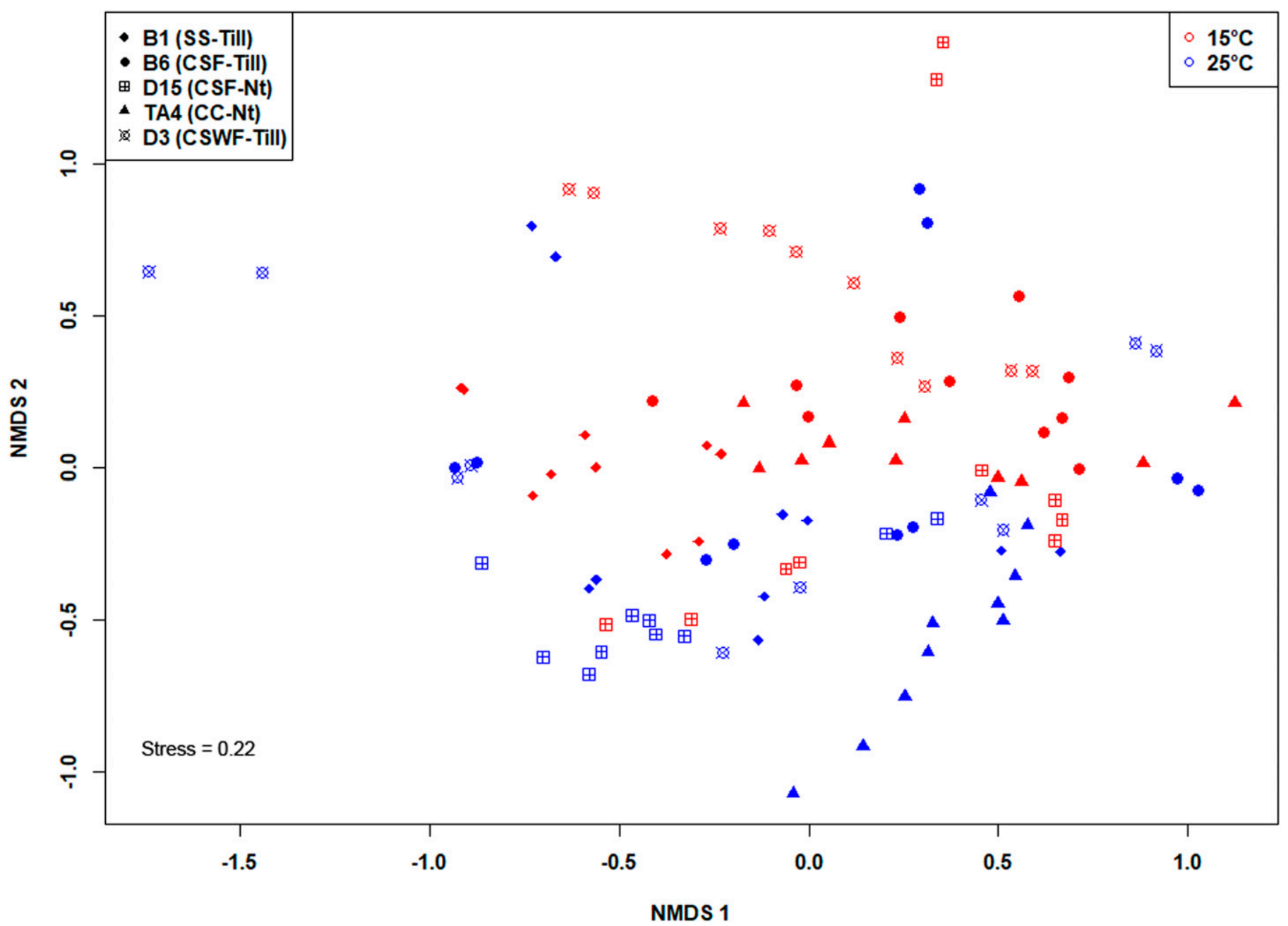

Fig. 1. Nonmetric multidimensional scaling (NMDS) plots using Bray-Curtis dissimilarity of Phytophthora, Phytopythium, and Pythium community data from soils collected from five fields on the same 81 -ha farm following incubation at 15 and $25^{\circ} \mathrm{C}(n=10)$ (culture-independent analyses). Stress values for NMDS are shown in the bottom left of the plot. The effect of field (permutation analysis of variance [PERMANOVA]; $P=0.001 ; R^{2}=0.23$ ), temperature (PERMANOVA; $P=0.001 ; R^{2}=0.04$ ), and the interaction of field and temperature (PERMANOVA; $P=0.001 ; R^{2}=0.10$ ) were significantly different. Replicates and run were not statistically different (PERMANOVA; $P=1.0 ; R^{2}=0.004$ ). Crops and tillage practices: field B1 with continuous soybean and tilled (SS-Till), field B6 with corn-soybean-fallow rotation and tilled (CSF-Till), field D15 with corn-soybean-fallow and no till (CSF-Nt), field TA4 with continuous corn and no till (CC-Nt), and D3 with corn-soybean-wheat-fallow rotation and tilled (CSWF-Till). 
voucher specimens deposited at the NCBI nucleotide nonredundant database (Hyde et al. 2014; Levesque and de Cock 2014: Robideau et al. 2011).
Rhizosphere soil DNA extraction. Rhizosphere soil collected from all five seedlings from each individual pot was first ground using a blender (Grainger Inc., Lake Forest, IL, U.S.A.) to make
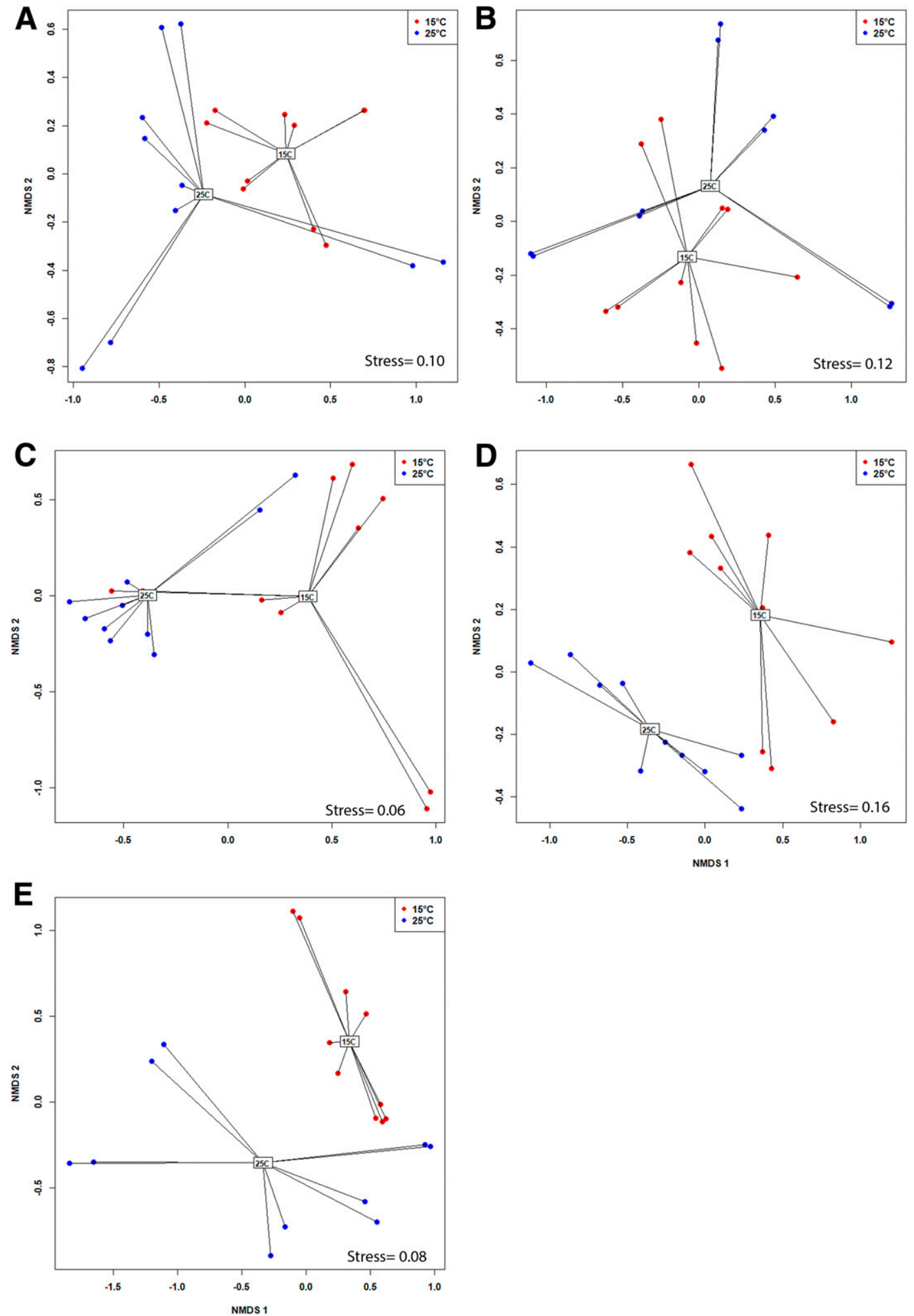

Fig. 2. Nonmetric multidimensional scaling plots (NMDS) using Bray-Curtis dissimilarity of Phytophthora, Phytopythium, and Pythium community data from five fields following incubation at 15 and $25^{\circ} \mathrm{C}(n=10)$ (culture-independent analyses). NMDS plots are shown for $\mathbf{A}$, field D15 with corn-soybeanfallow and no till (CSF-Nt); B, field B1 with continuous soybean and tilled (SS-Till); C, field B6 with corn-soybean-fallow rotation and tilled (CSF-Till); D, field TA4 with continuous corn and no till (CC-Nt); and E, field D3 with corn-soybean-wheat-fallow rotation and tilled (CSWF-Till). Stress values for NMDS are shown in the bottom right. Lines are depicting convex hulls enclosing all samples pertaining to the two temperatures of incubation used for the baiting technique. 
TABLE 3

Total abundance of species of Phytophthora Phytopythium, and Pythium in the rhizosphere soil of soybean seedlings during soil baiting of soils from five fields following incubation at 15 and $25^{\circ} \mathrm{C}$ (culture-independent analyses) ${ }^{\mathrm{a}}$

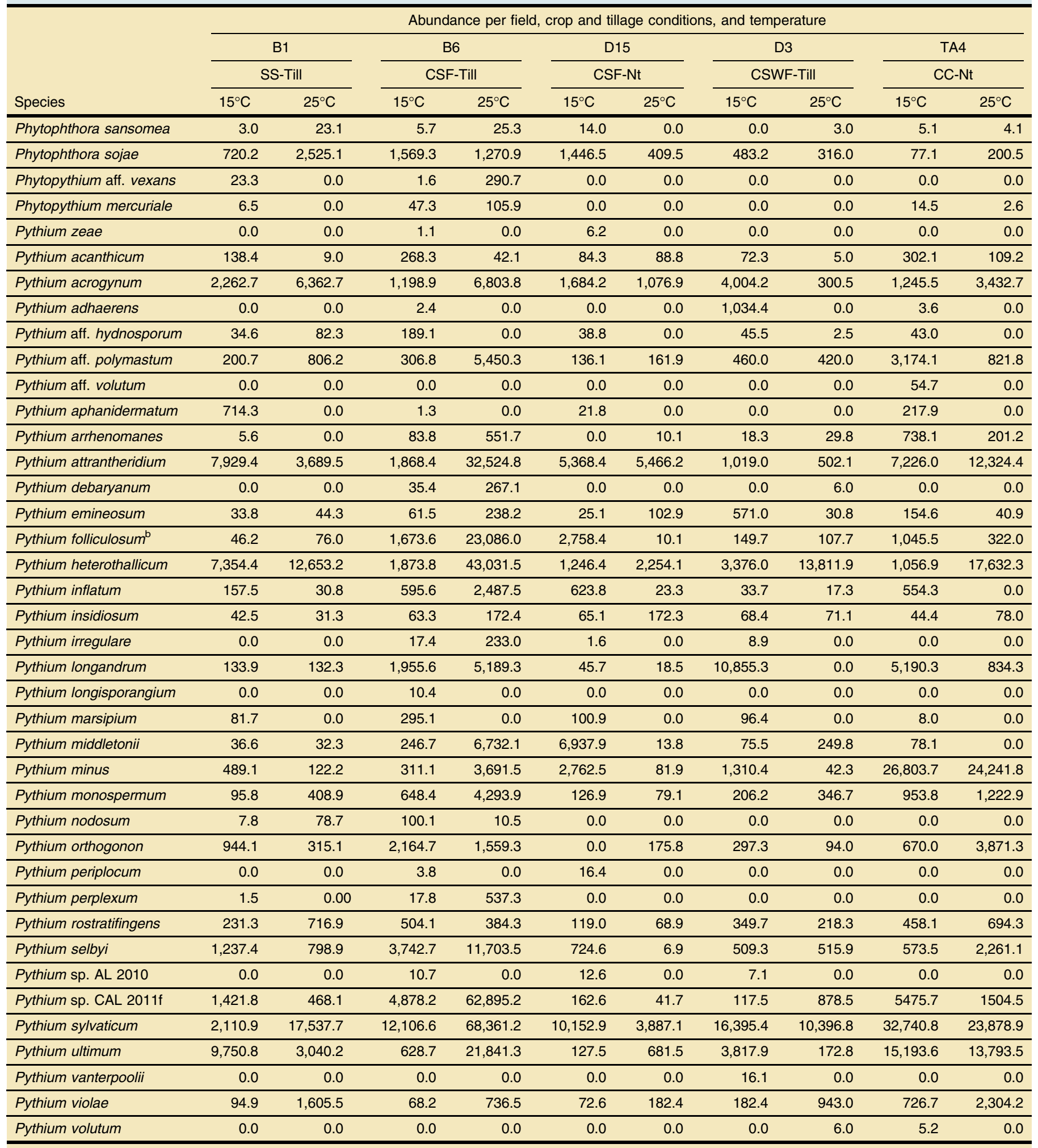

a Abundances are based on cumulative sum scaled normalized data. Pythium acrogynum, Pythium attrantheridium, Pythium heterothallicum, Pythium sylvaticum, and Pythium ultimum are species abundant in rhizosphere soil across all fields and incubation temperatures; Pythium acanthicum, Pythium adhaerens, Pythium aff. hydnosporum, Pythium aphanidermatum, Pythium marsipium, and Pythium nodosum are species favored when soils are incubated at $15^{\circ} \mathrm{C}$; Phytopythium aff. vexans, $P$. debaryanum, Pythium irregulare, Pythium monospermum, and Pythium violae are species favored when soils are incubated at $25^{\circ} \mathrm{C}$; and Pythium folliculosum, Pythium longandrum, Pythium middletonii, Pythium minus, Pythium selbyi, and Pythium sp. CAL $2011 \mathrm{f}$ are species where the abundance was different for temperature across fields. Abbreviations for rotation: SS-Till $=$ continuous soybean and tilled; CSF-Till = corn, soybean, fallow, and tilled; CSF-Nt = corn, soybean, and fallow with no till; CSWF-Till = corn, soybean, wheat, fallow, and tilled; and CC-Nt = continuous corn with no till.

b Pythium folliculosum represents all of the species in Pythium clade B; for this and others that have identical internal transcribed spacer 1 sequences, please refer to Supplementary Table S2. 
samples homogenous and for easier handling. The DNeasy Power Lyzer Power Soil Kit (Qiagen, Carlsbad, CA, U.S.A.) was used to extract the DNA following the manufacturer's protocol, with some modifications. Modifications included the Power Lyzer Homogenizer (Qiagen ) was set at 4,000 rpm for $45 \mathrm{~s}$, incubation of sample at $2^{\circ} \mathrm{C}$ for $5 \mathrm{~min}$, and then dilution of DNA with $50 \mu \mathrm{l}$ of solution C6 from the kit. Quality and quantity of DNA were assessed as described above.

Sequencing of rhizosphere DNA from soils incubated at 15 and $25^{\circ} \mathrm{C}$. In total, three DNA extractions were performed from the rhizosphere soil collected from the five seedlings from each pot. The three DNA extractions were then pooled equimolarly for a final concentration of $5 \mathrm{ng} / \mu \mathrm{l}$. Pooled DNA was then amplified using the Phusion High-Fidelity DNA Polymerase (New England BioLabs, Ipswich, MA, U.S.A.), which minimizes PCR errors. The reaction consisted of $5 \mu \mathrm{l}$ of $5 \times$ High Fidelity Buffer, $0.5 \mu$ l of nucleotide $\operatorname{mix}(10 \mu \mathrm{M}), 1 \mu \mathrm{l}$ of each primer ITS6 and ITS7 $(2 \mu \mathrm{M})$ containing Illumina adapters, $5 \mu \mathrm{l}$ of template $(5 \mathrm{ng} / \mu \mathrm{l}), 0.2 \mu \mathrm{l}$ of Phusion Taq (1.0 U per $50-\mu 1$ PCR), and $9.3 \mu$ l of ultrapure water. PCR was performed using the following parameters: $96^{\circ} \mathrm{C}$ for $3 \mathrm{~min}$; followed by 25 cycles of $96^{\circ} \mathrm{C}$ for $30 \mathrm{~s}, 55^{\circ} \mathrm{C}$ for $30 \mathrm{~s}$, and $72^{\circ} \mathrm{C}$ for 30 $\mathrm{s}$; and completed with $72^{\circ} \mathrm{C}$ for $5 \mathrm{~min}$.

PCR products. There were two technical PCR replicates for each pool which were then submitted to the MCIC for library preparation and sequencing.

Library preparation and Illumina MiSeq amplicon sequencing. A second round of PCR was performed to add the Illumina adapter sequence, which contains a unique dual combination of the Nextera indices for individual barcodes for each sample. The first PCR product $(3 \mu \mathrm{l})$ was then used as input for the second PCR. The PCR products were purified after each PCR amplification using the Agencourt AMPure XP beads (Beckman Coulter Life Sciences). All of the steps for library preparation and cleaning were carried out on the epMotion5075 automated liquid handler (Eppendorf). The amplicon libraries were quantified and pooled at equimolar ratios before sequencing. The final pool was purified using the Pippin Prep size selection system (Sage Science) to discard the presence of any primer dimers. The MiSeq sequencing platform (Illumina) was used for amplicon sequencing at a final concentration of $14.3 \mathrm{pM}$. Amplicon libraries were spiked with PhiX libraries (approximately 20\%) to allow a more heterogeneous sample and reduce error in the run introduced by the high levels of similar nucleotides among oomycetes. The run was clustered to a density of $905 \mathrm{k} / \mathrm{mm}^{2}$ and the libraries were sequenced using a 300 PE MiSeq sequencing kit with the standard Illumina sequencing primers. Image analysis, base calling, and data quality assessment were performed on the MiSeq platform.

Amplicon sequence data processing. The ITS1 sequence data generated from rhizosphere soil were processed using the USEARCH pipeline (Bakker et al. 2017; Edgar 2010) and custom scripts. The removal of the Illumina barcodes as well as merging of the short pair-end reads was done using BBMerge in BBTools suite, version 3 (Bushnell et al. 2017). Quality filtering was done using the -fastq_filter command in USEARCH with a threshold of $1 \%$ expected number of errors (Edgar and Flyvbjerg 2015). After quality filtering, the ITS1 region was extracted using the ITSx software (Bengtsson-Palme et al. 2013), version 1.0.11. Dereplication was performed using the fastx_uniques command to find a set of unique sequences and remove duplicate shorts reads from the initial reads set. Dereplicated short reads were then analyzed using the operational taxonomic unit (OTU) approach. For OTU clustering, reads were clustered de novo at the $97 \%$ similarity level using the UPARSE distance-based greedy-approach algorithm implemented in the -cluster_otus command (Edgar 2013). In order to correct sequencing errors and remove chimeric reads, the UNOISE algorithm as implemented in the -unoise 3 command was run. The denoised sequences were then used to create the OTU table using the -otutab command. Finally, taxonomy was assigned to OTUs using the -sintax command with $100 \%$ cutoff with a custom-made database. The database was custom made and composed of full ITS sequence accessions retrieved from Hyde et al. (2014), Lévesque and de Cock (2004), and Robideau et al. (2011) in addition to internal sequences generated from the laboratory during previous surveys (Supplementary Table S1). The database was trimmed to only the ITS1 region using the ITSx software (Bengtsson-Palme et al. 2013), version 1.0.11. Further filtering steps and data analysis were carried out using the phyloseq (McMurdie and Holmes 2013), MetagenomeSeq (Paulson et al. 2013), and Vegan (Oksanen et al. 2019) packages in $R$, version 3.5.0. The sequence data were deposited to NCBI Sequence Read Archive SRR10479281 (DNA extraction pools) and SRR10492905 (comparison of 15 and $25^{\circ} \mathrm{C}$ ).

Phylogenetic analysis of the ITS1 among Pythium spp. and OTU assignments. Some species of Phytophthora and Pythium share identical ITS1 sequences, and this is a challenge faced by others in microbiome studies (Redekar et al. 2019). For this study, a customized database was developed from accessions of ITS1 and ITS2 and the 5.8 gene of the nuclear rRNA of voucher specimens used by Lévesque and de Cock (2004); sequences were retrieved from NCBI nucleotide database. From these accessions, the ITS1 region was extracted using the ITSx software (Bengtsson-Palme et al. 2013), version 1.0.11. Extracted sequences were then aligned using ClustalW in MEGA, version 7.1 (Kumar et al. 2016). After alignment, pairwise distance analysis was conducted using the maximum composite likelihood model (Tamura et al. 2004). The sequence of the ITS1 region of one or more species within Pythium clades A, B, D, E, and I were identical and could not be differentiated (Supplementary Table S2). For example, using pairwise comparison of the ITS1, three species have the same identical sequence within Pythium clade A. In clade B, which has many of the reported pathogens of soybean, there was complete sequence similarity of the ITS1 region. For example, Pythium folliculosum shares identical sequence with Pythium torulosum and Pythium catenulatum. However, Pythium folliculosum is rarely found in Ohio but Pythium torulosum has been frequently recovered from both corn and soybean. Similarly, Pythium arrhenomanes shares identical sequence with Pythium aristosporum, the causal agent of root dysfunction in creeping bentgrass and Pythium root rot of wheat (Chamswarng and Cook 1985). In Pythium clade D, the species Pythium amasculinum, Pythium oligandrum, and Pythium aff. hydnosporum shared identical sequences. The sequence of this ITS1 region is also identical between Pythium ultimum var. sporangiiferum and Pythium ultimum var. ultimum, which belong to clade I. From clade E, Pythium acrogynum and Pythium hypogynum share identical sequences. For those species, both known and unknown, that have identical sequences, the name of the first species in the clade was used in all of the analyses and in the figures and tables.

Direct isolation and amplicon sequence data analysis. Species richness for the isolates recovered through direct isolation was visualized as a proportion of isolates recovered compared with the total number of isolates from each sample. Due to the low number of isolates recovered from each sample, diversity indices were not calculated.

Statistical analysis of the data for Phytophthora, Phytopythium, and Pythium spp. only were selected for further analyses. To assess species richness and evenness from read count data, the Shannon's diversity index was calculated using the Vegan package (Oksanen et al. 2019) as implemented in $\mathrm{R}$ ( $\mathrm{R}$ Core Team 2018). To test whether the Shannon's index was different between samples and 
across the incubation temperatures, a two-way analysis of variance (ANOVA) was performed. Temperature and field were used as main effects and technical replicates were nested inside biological replicates.

Prior to calculating $\beta$ diversity, amplicon data were normalized to cumulative-sum scaling using the package Metagenomeseq in $\mathrm{R}$ (Paulson et al. 2013). Normalized data were then converted to relative abundances by dividing the absolute abundance of each OTU by the total number of sequences per sample. A Bray-Curtis dissimilarity matrix was then calculated from relative abundance data and the output matrix was used as input data for the nonmetric multidimensional scaling ordination plots. A permutation analysis of variance (PERMANOVA) was conducted with the adonis function to assess the significance of temperature, field, and the interaction of field and temperature in the community composition (Anderson 2001). Due to significant interactions of field and incubation temperature, the data were analyzed by each field separately using temperature as the main effect. Finally, the species richness from the amplicon sequencing approach was visualized as a proportion of reads compared with the total reads found on each sample. These data were then used for an ANOVA with SAS (9.4) to evaluate the main effects of the field sampled, incubation temperature, and the field-temperature interaction for each species.

\section{RESULTS}

The effect of soil-baiting incubation temperature and field on oomycete species diversity. The final dataset for the oomycete amplicon sequence of rhizosphere soil collected from soybean seedlings planted in soils incubated at 15 and $25^{\circ} \mathrm{C}$ consisted of $1,343,151$ ITS 1 sequence reads. Read depth for each sample ranged from 232,787 to 294,648 sequence reads. There were 5,948 OTUs in total, and only 3,563 were kept after normalization. The primers ITS6 and ITS7 also captured OTUs representing 13 nonoomycetes phyla, including the Ascomycota and Basidiomycota (Supplementary Fig. S2). For this article, only oomycetes were analyzed, which comprised 101 OTUs that were classified within the genera Phytophthora, Phytopythium, and Pythium. This subset of the data was then used for further analysis and comparisons. A minimum of 100 reads was used as a detection threshold to determine whether a distinct ITS sequence or "species" was present in the sample.

$\alpha$ and $\beta$ Diversity and abundant species based on amplicon sequencing. The Shannon's diversity index for the species of Phytophthora, Phytopythium, and Pythium was higher in the soils incubated at $15^{\circ} \mathrm{C}$ compared with $25^{\circ} \mathrm{C}$ in fields B6 (CSF-Till) and TA4 (CC-Nt) (ANOVA; $P<0.001$ ) (Table 2). Temperature also played a role in $\beta$ diversity. Based on the PERMANOVA, a significant difference in the community structure was observed between the two temperatures $(P=0.001)$, among the five fields $(P=$ $0.001)$, and, more importantly, for the interaction between temperature and field $(P=0.001)$ (Fig. 1). Due to significant interaction between temperature and field, the effect of temperature individually for each field was plotted (Fig. 2A to E). There was a separation of communities based on temperature for all fields (PERMANOVA; $P<001$ ) Regardless of the field site and incubation temperature, the species Pythium acrogynum, Pythium attrantheridium, Pythium heterothallicum, Pythium sylvaticum, and Pythium ultimum were highly abundant (Table 3).

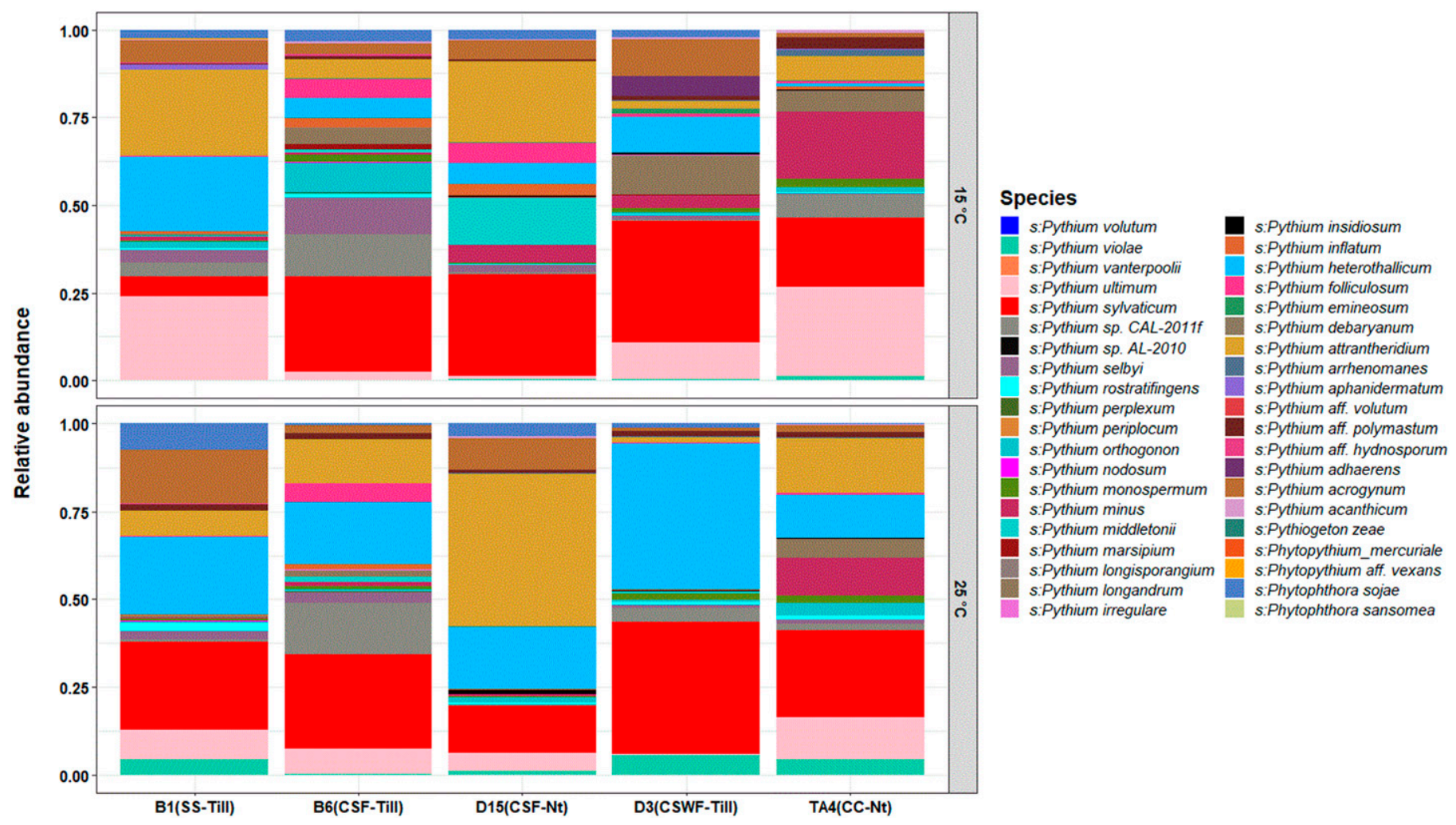

Fig. 3. Relative abundance based on cumulative sum scaling normalized counts $(n=10)$ of Phytophthora, Phytopythium, and Pythium spp. present in the rhizosphere soil of soybean seedlings following soil incubation at 15 and $25^{\circ} \mathrm{C}$ during baiting (culture-independent analyses). Crops and tillage practices: field B1 with continuous soybean and tilled (SS-Till), field B6 with corn-soybean-fallow rotation and tilled (CSF-Till), field D15 with cornsoybean-fallow and no till (CSF-Nt), field D3 with corn-soybean-wheat-fallow rotation and tilled (CSWF-Till), and field TA4 with continuous corn and no till (CC-Nt). 
Species composition associated with incubation temperature based on amplicon sequencing. Temperature and the field sampled affected the abundance of Phytophthora sojae and several species of Pythium. For example, in soils incubated at $15^{\circ} \mathrm{C}$, the species Pythium acanthicum $(P=0.006)$ and Pythium marsipium $(P=$ 0.0180 ) were more abundant in most fields compared with soils incubated at $25^{\circ} \mathrm{C}$, while Pythium aphanidermatum $(P=0.0805)$ and Pythium aff. hydnosporum $(P=0.0624)$ had similar trends (Fig. 3; Tables 3 and 4). In contrast, Pythium heterothallicum $(P=$ $0.0076)$ and Pythium violae $(P=0.0021)$ were more abundant at 25 than at $15^{\circ} \mathrm{C}$. Interestingly, for Phytophthora sojae and several Pythium spp., there was a significant interaction between the temperature and the field which affected the abundance. This interaction was highly significant $(P<0.001)$ for Pythium attrantheridium, Pythium emineosum, Pythium middletonii, Pythium aff. polymastum, and Pythium periplocum; significant $(P<0.05)$ for Pythium sylvaticum; and trending $(P<0.100)$ for Pythium orthogonon, Phytophthora sojae, Pythium debaryanum, and Pythium CAL 2011 (Fig 3; Tables 3 and 4) Among these field B6 (CSF Till) had significantly greater abundance of Pythium aff. polmastrum and Pythium attrantheridium $(P<0.05)$ at 25 compared with $15^{\circ} \mathrm{C}$. There was also a greater abundance of Pythium emineousum and Pythium sylvaticum $(P<0.05)$ in D3 (CSWF-Till) at 15 compared with $25^{\circ} \mathrm{C}$. Pythium insidiosum, although found at a low level, was marginally $(P=0.0938)$ influenced by baiting temperature. In field D15 (CSF-Nt), this species trend was for a greater number of relative reads $(P<0.1096)$ when soils were incubated at 25 compared with $15^{\circ} \mathrm{C}$.

Species diversity identified through direct isolation. There were 108 isolates of Pythium representing 10 different species isolated from symptomatic root tissue sampled only 3 days after plating onto selective media (Fig. 4). Based on the ITS1 sequence, Pythium sylvaticum from clade $\mathrm{F}$ and Pythium ultimum from clade I were the most prevalent, representing 48 and $36 \%$ of the total isolates recovered, respectively. Other species recovered at a lower frequency included Pythium attrantheridum, Pythium heterothallicum, Pythium hypogynum, Pythium inflatum, Pythium middletoni, Pythium perplexum, Pythium torulosum, and Pythium oopapillum. The temperature at which soils were incubated also impacted which species were recovered via direct isolation. Pythium attrantheridium, Pythium oopapillum, and Pythium torulosum were only isolated at $15^{\circ} \mathrm{C}$ while Pythium middletoni, Pythium heterothallicum, and Pythium inflatum were only isolated at $25^{\circ} \mathrm{C}$. There were similar numbers of isolates recovered from the different field sites at each temperature, with two to six different species (Fig. 4).

\section{DISCUSSION}

Many species of Phytophthora, Phytopythium, and Pythium have been recovered during surveys of soybean and corn seedling pathogens in the north-central region of the United States (Broders

TABLE 4

Summary of the $P$ values from an analysis of variance for the effect of temperature (Temp), field sampled, or their interaction among the 39 species of Phytophthora, Pythium, and Phytopythium detected in the soybean rhizosphere from an 81-ha research farm in northwest Ohio following a soil-baiting study ${ }^{a}$

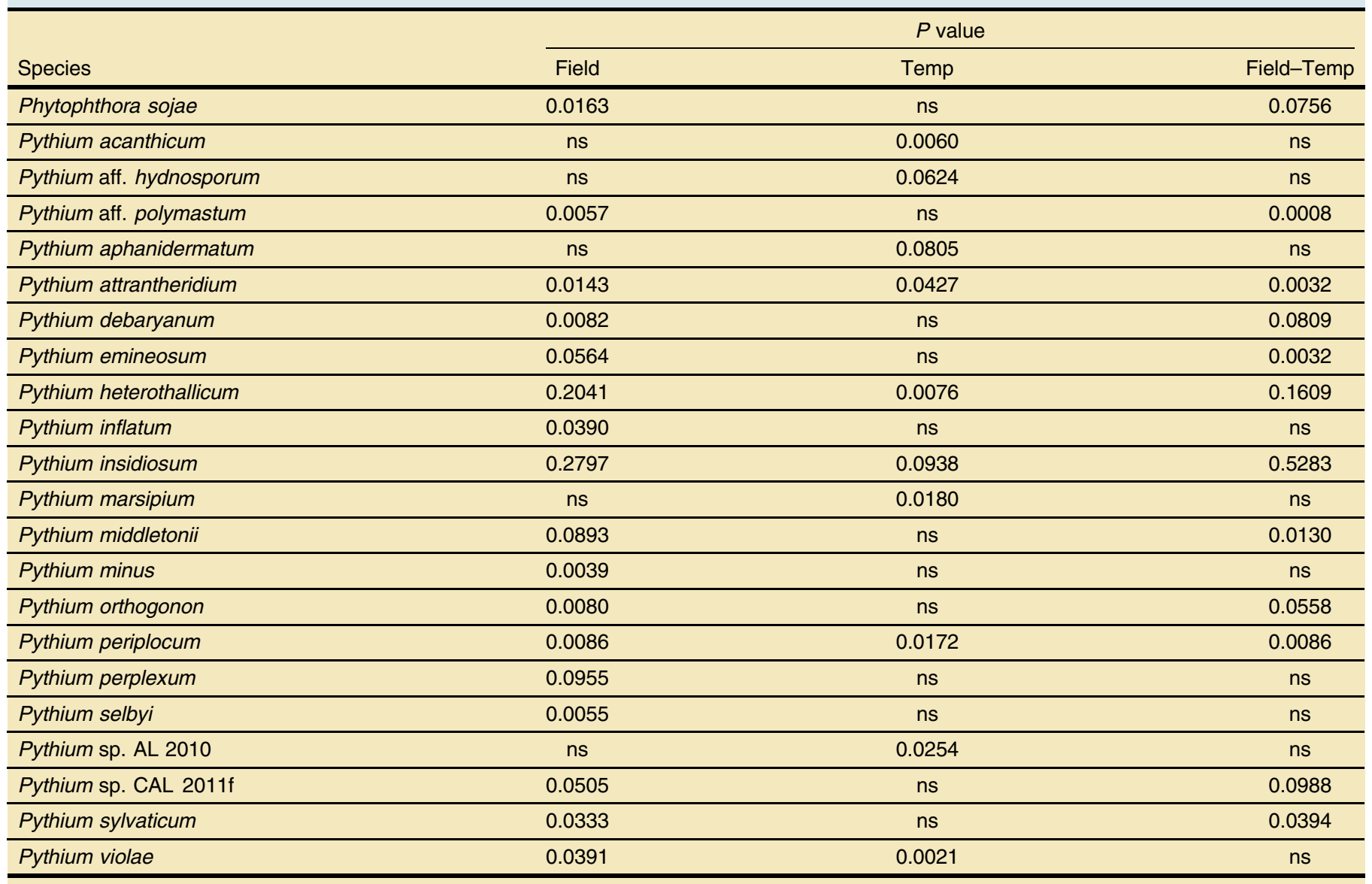

a Five study sites were sampled in the 81-ha farm, each with a different history of production practices; however, soil parameters were all similar. Soils were incubated at two different temperatures prior to soil baiting $\left(15\right.$ or $\left.25^{\circ} \mathrm{C}\right)$; ns = not significant. 
et al. 2007, 2009; Dorrance et al. 2004; Jiang et al. 2012; Radmer et al. 2017; Rojas et al. 2017a; Zhang et al. 1998; Zhang and Yang 2000; Zitnick-Anderson and Nelson 2015). Using traditional culturing methods directly from field-collected samples or soil baiting, these studies attributed species diversity and disease development to numerous factors that included rainfall after planting, soil edaphic factors, and latitude. Often, the effect of these factors on species composition were explored in surveys that cover a wide geographical region, different environmental conditions prior to sample collection, and from fields that often have very different soil characteristics. In this study, the soil composition was very similar among the five separate field sites, allowing us to evaluate the effects of incubation temperature during baiting on the detection of species of Phytophthora, Phytopythium, and Pythium affecting soybean.

The primary hypothesis we examined was accepted as soil incubation temperature affected the species composition of Phytophthora, Phytopythium, and Pythium associated with the soybean rhizosphere. The species that were significantly affected by temperature could be part of the complex of species affecting soybean and provide further evidence that temperature at planting may play a pivotal role in disease development. There is a need to understand whether the different combinations of species enhance or inhibit seedling disease development, or how these are affected by other environmental factors, in order to be able to provide targeted disease management practices such as seed treatments or host resistance.

Although incubation temperature was found to affect the species abundance and species diversity of Phytophthora, Phytopythium, and Pythium, a few species were not affected. For example, among the more than 30 OTU detected, Pythium sylvaticum, Pythium ultimum, Pythium attrantheridium, and Pythium heterothallicum were highly abundant across all samples. These species were frequently recovered in previous surveys across several of the soybean-producing states (Broders et al. 2007; Dorrance et al. 2004; Kirkpatrick et al. 2006; Radmer et al. 2017; Rojas et al. 2017a) and some have also been reported as highly pathogenic toward soybean, albeit at different temperatures (Radmer et al. 2017). This suggests

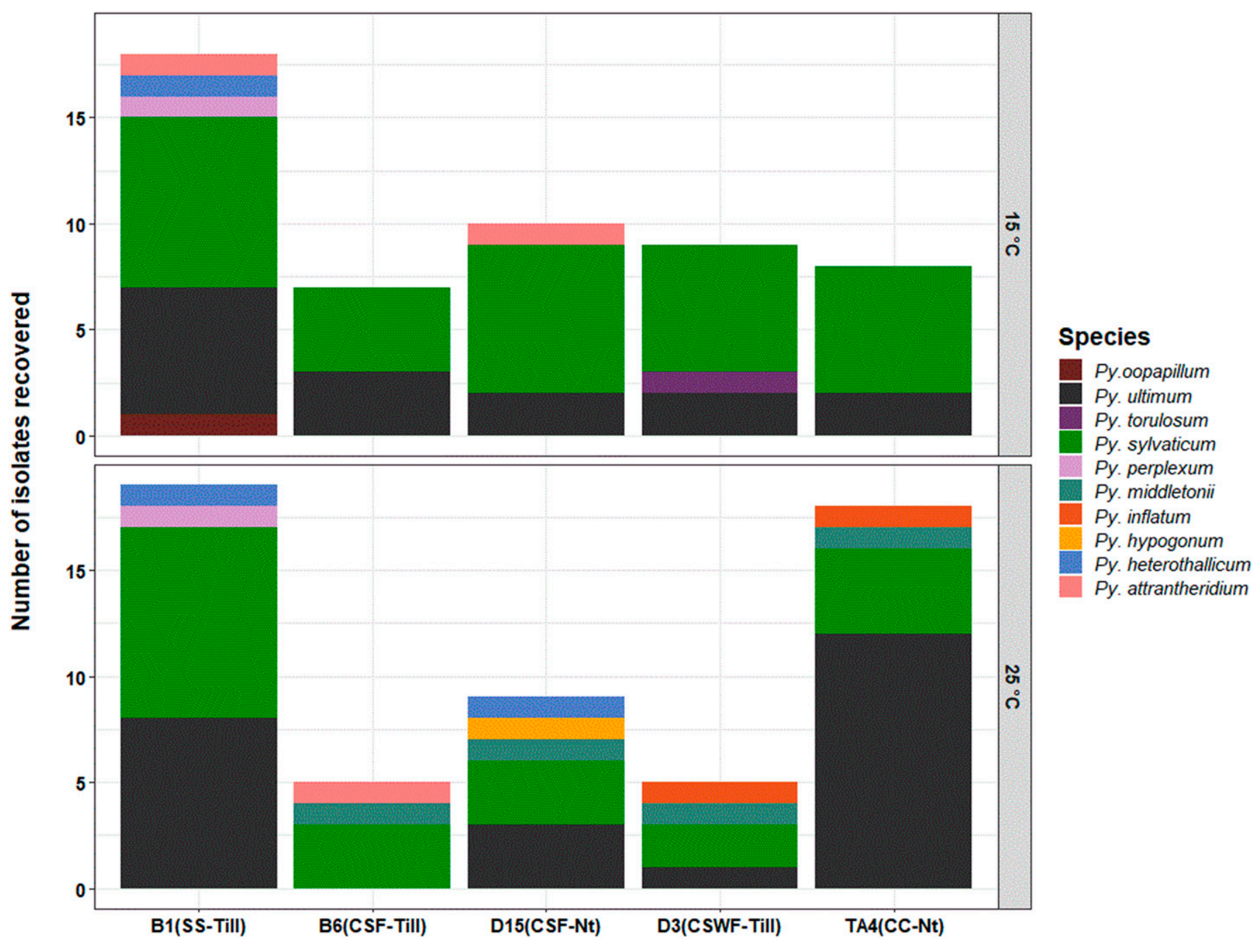

Fig. 4. Distribution of Pythium spp. recovered using a culture-dependent approach from seedlings that were used as bait from soils collected from five fields with different production practices following incubation at 15 and $25^{\circ} \mathrm{C}$. Isolates were recovered from seedlings of the susceptible soybean cultivar Sloan 3 days after flooding for $24 \mathrm{~h}$. Identification of species was performed using the internal transcribed spacer (ITS) 6 and ITS7 primers which only amplified the ITS1 region of the ribosomal RNA gene. In total, five symptomatic seedlings per field were collected for each temperature. Crops and tillage practices: field B1 with continuous soybean and tilled (SS-Till), field B6 with corn-soybean-fallow rotation and tilled (CSF-Till), field D15 with corn-soybean-fallow and no till (CSF-Nt), field D3 with corn-soybean-wheat-fallow rotation and tilled (CSWF-Till), and field TA4 with continuous corn and no till (CC-Nt). 
that these maybe the most prevalent species of Pythium responsible for seedling disease in soybean and should be the primary focus for disease management. Among these most prevalent species, Pythium heterothallicum is considered a common soilborne saprophyte (Van der Plaats-Niterink 1981) but there are reports where pathogenicity has been observed (Chamswarng and Cook 1985; Coffua et al. 2016; Gan et al. 2010; Ingram and Cook 1990; Zitnick-Anderson and Nelson 2015), and it was hypothesized to be part of a species complex with Pythium glomeratum (Robideau et al. 2011). In this study, Pythium glomeratum was not detected; however, the high levels of Pythium heterothallicum suggest that this species may form a complex with other species, and this should be explored further.

The amplicon sequencing approach relative to direct isolation resulted in a higher resolution of species diversity and abundance from these soybean rhizosphere samples. However, the sequence of the ITS1 region alone is identical for some species within the same clade, and these can only be distinguished using morphological structures. This was also discussed in the study by Redekar et al. (2019), where Pythium spp. were found in nursery recycled irrigation water. For Pythium spp., the full sequence encompassing the ITS1 and ITS2 and the 5.8 gene operon can distinguish between species with globose and filamentous sporangium (Lévesque and de Cock 2004). In the previous survey conducted by Broders et al. (2007), Pythium dissotocum was the most frequently recovered but this species could not be distinguished from other members of clade $\mathrm{B}$ in this study due to the sequence similarity (Lévesque and de Cock 2004).

There were sequences of two species, Pythium insidiosum and the undescribed Pythium sp. CAL, detected with amplicon sequencing but not isolated from plant tissue in this study. Pythium insidiosum, known to cause pythiosis in mammals (de Cock et al. 1987), was detected in fields with continuous soybean and is usually found in tropical and subtropical climates such as agricultural irrigation water and soil in Thailand (Supabandhu et al. 2008; Vanittanakom et al. 2014). In the United States, in north-central Florida, this species was found in 11 of the 19 lakes and ponds sampled (Presser and Goss 2015). In Ohio, this study is the first to report Pythium insidiosum from rhizosphere soils of soybean seedlings using a soil-baiting technique. Although this species is not pathogenic toward soybean, this could also be a related species that shares the same identical ITS1 sequence and thus, should be further confirmed using species specific probes. The species Pythium sp. CAL has been previously isolated from soybean roots grown under PBNIC media at an incubation temperature of $23^{\circ} \mathrm{C}$ (Zitnick-Anderson and Nelson 2015), which suggests that warmer temperatures are required for growth. It may also require more time to grow, because our baiting procedure was limited to 3 days after planting; thus, it may have been missed in this study when we tried to recover it from seedling root tissue. Due to greater abundance of Pythium sp. CAL found across all temperatures and fields, more studies should be conducted to understand its role in disease of soybean.

Deciphering the species diversity of Phytophthora, Phytopythium, and Pythium that can form when different temperatures are encountered can enable the development of more targeted disease management practices. The incubation temperature during soil baiting greatly influenced the species that were identified through both direct isolation and amplicon sequencing. These results may explain, in part, the difference among species recovered from the many surveys across the United States that have attempted to identify the cause of soybean seed and seedling damping-off. Interestingly only 5 of the 31 species detected in this study were not influenced by temperature or field sampling site, and these would represent very good targets for the evaluation of seed treatment products and breeding for disease resistance.

\section{ACKNOWLEDGMENTS}

We thank S. Veney, G. Hayward Lara, and D. Veney for assistance during sample processing; The Ohio State University Northwest Agricultural Research Station crew M. Davis, N. Davis, C. Jones, and J. Zeitner for sample collection and soil property data; F. Dalla Lana for assistance in data visualization in R; and P. Paul for assistance in statistical analysis.

\section{LITERATURE CITED}

Allen, T. W., Bradley, C. A., Sisson, A. J., Byamukama, E., Chilvers, M. I., Coker, C. M., Collins, A. A., Damicone, J. P., Dorrance, A. E., Dufault, N. S., Esker, P. D., Faske, T. R., Giesler, L. J., Grybauskas, A. P., Hershman, D. E., Hollier, C. A., Isakeit, T., Jardine, D. J., Kelly, H. M., Kemerait, R. C., Kleczewski, N. M., Koenning, S. R., Kurle, J. E., Malvick, D. K., Markell, S. G., Mehl, H. L., Mueller, D. S., Mueller, J. D., Mulrooney, R. P., Nelson, B. D., Newman, M. A., Osborne, L., Overstreet, C., Padgett, G. B., Phipps, P. M., Price, P. P., Sikora, E. J., Smith, D. L., Spurlock, T. N., Tande, C. A., Tenuta, A. U., Wise, K. A., and Wrather, J. A. 2017. Soybean yield loss estimates due to diseases in the United States, and Ontario, Canada, from 2010 to 2014. Plant Health Prog. 18:19-27.

Anderson, M. J. 2001. A new method for non-parametric multivariate analysis of variance. Aust. Ecol. 26:32-46.

Bakker, M. G., Moorman, T. B., Kaspar, T. C., and Manter, D. K. 2017. Isolation of cultivation-resistant oomycetes, first detected as amplicon sequences, from roots of herbicide-terminated winter rye. Phytobiomes J. 1:24-35.

Bengtsson-Palme, J., Ryberg, M., Hartmann, M., Branco, S., Wang, Z., Godhe, A., De Wit, P., Sánchez-García, M., Ebersberger, I., de Sousa, F., Amend, A., Jumpponen, A., Unterseher, M., Kristiansson, E., Abarenkov, K., Bertrand, Y. J. K., Sanli, K., Eriksson, K. M., Vik, U., Veldre, V., and Nilsson, R. H. 2013. Improved software detection and extraction of ITS1 and ITS2 from ribosomal ITS sequences of fungi and other eukaryotes for analysis of environmental sequencing data. Methods Ecol. Evol. 4:914-919.

Broders, K. D., Lipps, P. E., Paul, P. A., and Dorrance, A. E. 2007. Evaluation of Fusarium graminearum associated with corn and soybean seed and seedling disease in Ohio. Plant Dis. 91:1155-1160.

Broders, K. D., Wallhead, M. W., Austin, G. D., Lipps, P. E., Paul, P. A., Mullen, R. W., and Dorrance, A. E. 2009. Association of soil chemical and physical properties with Pythium species diversity, community composition, and disease incidence. Phytopathology 99:957-967.

Bushnell, B., Rood, J., and Singer, E. 2017. BBMerge-Accurate paired shotgun read merging via overlap. PLoS One 12:e0185056.

Chamswarng, C., and Cook, R. J. 1985. Identification and comparative pathogenicity of Pythium species from wheat roots and wheat-field soils in the Pacific Northwest. Phytopathology 75:821-827.

Coffua, L. S., Veterano, T., Clipman, S. J., Mena-Ali, J. I., and Blair, J. E. 2016. Characterization of Pythium spp. associated with asymptomatic soybean in southeastern Pennsylvania. Plant Dis. 100:1870-1879.

Cooke, D. E., Drenth, A., Duncan, J. M., Wagels, G., and Brasier, C. M. 2000. A molecular phylogeny of Phytophthora and related oomycetes. Fungal Genet. Biol. 30:17-32.

Cooke, D. E., and Duncan, J. M. 1997. Phylogenetic analysis of Phytophthora species based on ITS1 and ITS2 sequences of the ribosomal RNA gene repeat. Mycol. Res. 101:667-677.

de Cock, A. W., Mendoza, L., Padhye, A. A., Ajello, L., and Kaufman, L. 1987. Pythium insidiosum sp. nov., the etiologic agent of pythiosis. J. Clin. Microbiol. 25:344-349.

de Cock, A. W. A. M., Lodhi, A. M., Rintoul, T. L., Bala, K., Robideau, G. P., Abad, G. Z., Coffey, M. D., Shahzad, S., and Lévesque, C. A. 2015. Phytopythium: Molecular phylogeny and systematics. Persoonia 34:25-39.

Donaldson, S. P., and Deacon, J. W. 1993. Changes in motility of Pythium zoospores induced by calcium and calcium-modulating drugs. Mycol. Res. 97:877-883.

Dorrance, A. E. 2018. Management of Phytophthora sojae of soybean: A review and future perspectives. Cana. J. Plant Pathol. 40:210-219.

Dorrance, A. E., Berry, S. A., Anderson, T. R. and Meharg, C. 2008. Isolation, storage, pathotype characterization, and evaluation of resistance for 
Phytophthora sojae in soybean. Plant Health Prog. 9. https://apsjournals. apsnet.org/doi/10.1094/PHP-2008-0118-01-DG

Dorrance, A. E., Berry, S. A., Bowen, P., and Lipps, P. E. 2004. Characterization of Pythium spp. from three Ohio fields for pathogenicity on corn and soybean and metalaxyl sensitivity. Plant Health Prog. 5. https://apsjournals.apsnet.org/ doi/10.1094/PHP-2004-0202-01-RS

Edgar, R. 2010. Search and clustering orders of magnitude faster than BLAST. Bioinformatics 26:2460-2461.

Edgar, R. 2013. UPARSE: Highly accurate OTU sequences from microbial amplicon reads. Nat. Methods. 10:996-998.

Edgar, R., and Flyvbjerg, H. 2015. Error filtering, pair assembly and error correction for next-generation sequencing reads. Bioinformatics 31 : 3476-3482.

Erwin, D. C., and Ribeiro, O. K. 1996. Isolation and detection of Phytophthora. Pages 8-41 in: Phytophthora Diseases Worldwide. American Phytopathological Society Press, St. Paul, MN, U.S.A.

Fry, W. E., and Grünwald, N. J. 2010. Introduction to oomycetes. Plant Health Instruct. https://www.apsnet.org/edcenter/disandpath/oomycete/introduction/ Pages/IntroOomycetes.aspx 10.1094/PHI-I-2010-1207-01

Gan, H. L., Chai, Z. X., Lou, B. G., and Li, J. H. 2010. Pythium heterothallicum new to China and its pathogenicity. Mycosystema 29:494-501.

Hendrix, F. F., and Campbell, W. A. 1973. Pythiums as plant pathogens. Annu. Rev. Phytopathol. 11:77-98.

Hyde, K. D., Henrik Nilsson, R., Aisyah Alias, S., Ariyawansa, H. A., Blair, J. E., Cai, L., de Cock, W. A. M. A., Dissanayake, A. J., Glockling, S. L., Goonasekara, I. D., Gorczak, M., Hahn, M., Jayawardena, R. S., van Kan, J. A. L., Laurence, M. H., Lévesque C. A., Li, X., Liu, J. K., Maharachchikumbura, S. S. N., Manamgoda, D. S., Martin, F. N., McKenzie, E. H. C., McTaggart, A. R., Mortimer, P. E., Nair, P. V. R., Pawłowska, J., Rintoul, T. L., Shivas, R. G., Spies, C. F. J., Summerell, B. A., Taylor, P. W. J., Ter-hem, R. B., Udayanga, D., Vaghefi, N., Walther, G., Wilk, M., Wrzosek, M., Xu, J. C., Yan, J. Y., and Zhou, N. 2014. One stop shop: Backbone trees for important phytopathogenic genera: I. Fungal Diversity 67:211-125.

Ingram, D. M., and Cook, R. J. 1990. Pathogenicity of four Pythium species to wheat, barley, peas and lentils. Plant Pathol. J. 39:110-117.

Jiang, Y. N., Haudenshield, J. S., and Hartman, G. L. 2012. Characterization of Pythium spp. from soil samples in Illinois. Can. J. Plant Pathol. 34:448-454.

Kaufmann, M. J., and Gerdemann, J. W. 1958. Root and stem rot soybean caused by Phytophthora sojae n. sp. Phytopathology 48:201-208.

Kirkpatrick, M. T., Rupe, J. C., and Rothrock, C. S. 2006. Soybean response to flooded soil conditions and the association with soilborne plant pathogenic genera. Plant Dis. 90:592-596.

Kong, P., Richardson, P. A., and Hong, C. 2005. Direct colony PCR-SSCP for detection of multiple Pythiaceous oomycetes in environmental samples. J. Microbiol. Methods 61:25-32.

Kumar, S., Stecher, G., and Tamura, K. 2016. MEGA7: Molecular evolutionary genetics analysis version 7.0 for bigger datasets. Mol. Biol. Evol. 33: $1870-1874$.

Lenney, J. F., and Klemmer, H. W. 1966. Factors controlling sexual reproduction and growth in Pythium graminicola. Nature 209:1365-1366.

Lévesque, C. A., and de Cock, A. W. A. M. 2004. Molecular phylogeny and taxonomy of the genus Pythium. Mycol. Res. 108:1363-1383.

Martin, F., and Loper, J. 1999. Soilborne plant diseases caused by Pythium spp.: Ecology, epidemiology, and prospects for biological control. Crit. Rev. Plant Sci. 18:111-181.

Matthiesen, R. L., Ahmad, A. A., and Robertson, A. E. 2016. Temperature affects aggressiveness and fungicide sensitivity of four Pythium spp. that causes soybean and corn damping off in Iowa. Plant Dis. 100:583-591.

McMurdie, P. J., and Holmes, S. 2013. Phyloseq: An R Package for reproducible interactive analysis and graphics of microbiome census data. PLoS One 8: e61217.

Oksanen, J. F., Blanchet, G., Friendly, M., Kindt, R., Legendre, P., McGlinn, D., Minchin, P. R., O'Hara, R. B., Simpson, G. L., Solymos, P., Stevens, M. H. H., Szoecs, E., and Wagner, H. 2019. Vegan: Community Ecology Package. R package version 2.5-5. https://r.meteo.uni.wroc.pl/web/packages/vegan/ index.html

Paulson, J. N., Stine, O. C., and Corroda-Bravo, H. 2013. Differential abundance analysis for microbial marker-gene survey. Nat. Methods 10:1200-1202.

Presser, J. W., and Goss, E. M. 2015. Environmental sampling reveals that Pythium insidiosum is ubiquitous and genetically diverse in North Central Florida. Med. Mycol. 53:674-683.
Radmer, L., Anderson, G., Malvick, D. M., Kurle, J. E., Rendahl, A., and Mallik, A. 2017. Pythium, Phytophthora, and Phytopythium spp. associated with soybean in Minnesota, their relative aggressiveness on soybean and corn, and their sensitivity to seed treatment fungicides. Plant Dis. 101:62-72.

R Core Team. 2018. R: A Language and Environment for Statistical Computing. R Foundation for Statistical Computing, Vienna, Austria. https://www.Rproject.org/

Redekar, N. R., Eberhart, J. L., and Parke, J. L. 2019. Diversity of Phytophthora, Pythium and Phytopythium species in recycled irrigation water in a container nursery. Phytobiomes J. 3:31-45.

Robideau, G. P., de Cock, A. W., Coffey, M. D., Voglmayr, S., Brouwer, H., Bala, K., Chitty, D. W., Désaulniers, N., Eggertson, Q. A., Gachon, C. M., Chia-Hui, H., Küpper, F. C., Rintoul, T. L., Sarhan, E., Verstappen, E. C., Zhang, Y., Bonants, P. J., Ristaino, J. B., and Lévesque, C. A. 2011. DNA barcoding of oomycetes with cytochrome $c$ oxidase subunit I and internal transcribed spacer. Mol. Ecol. Resour. 11:1002-1011.

Rojas, A. J., Jacobs, J. L., Napieralski, S., Karaj, B., Bradley, C. A., Chase, T., Esker, P. D., Giesler, L. J., Jardine, D. J., Malvick, D. K., Markell, S. G., Nelson, B. D., Robertson, A. E., Rupe, J. C., Smith, D. L., Sweets, L. E., Tenuta, A. U., Wise, K. A., and Chilvers, M. I. 2017a. Oomycete species association with soybean seedlings in North America—Part I: Identification and pathogenicity characterization. Phytopathology 107:280-292.

Rojas, A. J., Jacobs, J. L., Napieralski, S., Karaj, B., Bradley, C. A., Chase, T., Esker, P. D., Giesler, L. J., Jardine, D. J., Malvick, D. K., Markell, S. G., Nelson, B. D., Robertson, A. E., Rupe, J. C., Smith, D. L., Sweets, L. E., Tenuta, A. U., Wise, K. A., and Chilvers, M. I. 2017b. Oomycete species associated with soybean seedlings in North America—Part II: Diversity and ecology in relation to environmental and edaphic factors. Phytopathology 107:293-304.

Rojas, J. A., Witte, A., Noel, Z. A., Jacobs, J. L., and Chilvers, M. I. 2019. Diversity and characterization of oomycetes associated with corn seedlings in Michigan. Phytobiomes J. 3:224-234.

Schmitthenner, A. F., and Van Doren, D. M., Jr. 1985. Integrated control of root rot of soybean caused by Phytophthora megasperma f. sp. glycinea. Pages 263-266 in: Ecology and Management of Soilborne Plant Pathogens. C. A. Parker, A. D. Rovira, K. J. Moore, P. T. W. Wong, and J. F. Kollmorgen, eds. American Phytopathological Society, St. Paul, MN, U.S.A.

Schroeder, K., Martin, F., de Cock, A. W., Lévesque, A., Spies, C., Okubara, P., and Paulitz, T. 2013. Molecular detection and quantification of Pythium species: Evolving taxonomy, new tools, and challenges. Plant Dis. 97:4-20.

Supabandhu, J., Fisher, M. C., Mendoza, L., and Nongnuch, V. 2008. Isolation and identification of the human pathogen Pythium insidiosum from environmental samples collected in Thai agricultural areas. Med. Mycol. 46: 41-52.

Tamura, K., Nei, M., and Kumar, S. 2004. Prospects for inferring very large phylogenies by using neighbor-joining methods. Proc. Natl. Acad. Sci. U.S.A. 101:11030-11035.

Thomson, T. B., Athow, K. L., and Laviolette, F. A. 1971. The effect of temperature on the pathogenicity of Pythium aphanidermatum, $P$. debaryanum, and P. ultimum on soybean. Phytopathology 61:933-935.

Uzuhashi, S., Tojo, M., and Kakishima, M. 2010. Phylogeny of the genus Pythium and description of new genera. Mycoscience 51:337-365.

Van der Plaats-Niterink, A. J. 1981. Monograph of the genus Pythium. Stud. Mycol. 21:1-242.

Vanittanakom, N., Szekely, J., Khanthawong, S., Sawutdeechaikul, P., Vanittanakom, P., and Fisher, M. C. 2014. Molecular detection of Pythium inisidiosum from soils in Thai agricultural areas. Int. J. Med. Microbiol. 304: 321-326.

Zhang, B. Q., Chen, W. D., and Yang, X. B. 1998. Occurrence of Pythium species in long-term maize and soybean monoculture and maize/soybean rotation. Mycol. Res. 102:1450-1452.

Zhang, B. Q., and Yang, X. B. 2000. Pathogenicity of Pythium populations from corn-soybean rotation fields. Plant Dis. 84:94-99.

Zitnick-Anderson, K. K., and Nelson, B. D. 2015. Identification and pathogenicity of Pythium on soybean in North Dakota. Plant Dis. 99: 31-38.

Zitnick-Anderson, K. K., Norland, J. E., del Rio-Mendoza, L. E., Fortuna, A., and Nelson, B. D. 2017. Probability models based on soil properties for predicting presence-absence of Pythium in soybean roots. Microb. Ecol. 74: $550-560$. 